\title{
The impact of over 100 years of wildfires on mercury levels and accumulation rates in two lakes in southern California, USA
}

\author{
Sarah E. Rothenberg $\cdot$ Matthew E. Kirby $\cdot$ \\ Broxton W. Bird · Margie B. DeRose · Chu-Ching Lin • \\ Xinbin Feng $\cdot$ Richard F. Ambrose $\cdot$ Jennifer A. Jay
}

Received: 10 September 2008/Accepted: 3 July 2009/Published online: 15 August 2009

(C) The Author(s) 2009. This article is published with open access at Springerlink.com

\begin{abstract}
In southern California, USA, wildfires may be an important source of mercury $(\mathrm{Hg})$ to local watersheds. $\mathrm{Hg}$ levels and $\mathrm{Hg}$ accumulation rates were investigated in dated sediment cores from two southern California lakes, Big Bear Lake and Crystal Lake, located approximately 40-km apart. Between 1895 and 2006, fires were routinely
\end{abstract}

\author{
S. E. Rothenberg $(\bowtie) \cdot$ R. F. Ambrose \\ Environmental Science and Engineering Program, \\ Department of Environmental Health Sciences, \\ University of California, Los Angeles, Box 951772, \\ CA 90095-1772, USA \\ e-mail: rothenberg.sarah@gmail.com \\ R. F. Ambrose \\ e-mail: rambrose@ucla.edu
}

M. E. Kirby - B. W. Bird - M. B. DeRose

Department of Geological Sciences, California State University,

Fullerton, Fullerton, CA 92834, USA

e-mail: mkirby@fullerton.edu

B. W. Bird

e-mail: broxton.bird@gmail.com

M. B. DeRose

e-mail: mdero001@email.ucr.edu

C.-C. Lin - J. A. Jay

Department of Civil and Environmental Engineering,

University of California, Box 951593, Los Angeles,

CA 90095-1593, USA

e-mail: chuching@gmail.com

J. A. Jay

e-mail: jjay@seas.ucla.edu

Present Address:

S. E. Rothenberg $\cdot$ X. Feng $(\square)$

State Key Laboratory of Environmental Geochemistry, Institute of Geochemistry, Chinese Academy of Sciences, Guiyang 550002, China

e-mail: fengxinbin@vip.skleg.cn minimized or suppressed around Big Bear Lake, while fires regularly subsumed the forest surrounding Crystal Lake. Mean $\mathrm{Hg}$ concentrations and mean $\mathrm{Hg}$ accumulation rates were significantly higher in Crystal Lake sediments compared to Big Bear Lake sediments (Hg levels: Crystal Lake $220 \pm 93 \mathrm{ng} \mathrm{g}^{-1}$, Big Bear Lake $92 \pm 26 \mathrm{ng} \mathrm{g}^{-1} ; \mathrm{Hg}$ accumulation: Crystal Lake $790 \pm 1,200 \mu \mathrm{g} \mathrm{m}^{-2}$ year $^{-1}$, Big Bear $240 \pm 54 \mu \mathrm{g} \mathrm{m}^{-2}$ year $^{-1}$ ). In Crystal Lake, the ratio between post-1965 and pre-1865 Hg concentrations was 1.1, and several spikes in Hg levels occurred between 1910 and 1985. Given the remote location of the lake, the proximity of fires, and the lack of point sources within the region, these results suggested wildfires (rather than industrial sources) were a continuous source of $\mathrm{Hg}$ to Crystal Lake over the last 150 years.

Keywords Mercury · California · Wildfires . Rapidly deposited layers · Turbidites

\section{Introduction}

Mercury $(\mathrm{Hg})$ is a naturally occurring element in the Earth's crust, which may be liberated through natural or anthropogenic means. Once released $\mathrm{Hg}$ may be transformed into methylmercury ( $\mathrm{MeHg}$ ), which is efficiently biomagnified in the aquatic food web. In the troposphere, $\mathrm{Hg}$ exists as gaseous elemental $\mathrm{Hg}\left(\mathrm{Hg}^{\mathrm{O}}\right)$, reactive gaseous mercury (RGM, consisting of oxidized gaseous $\mathrm{Hg}$ (II) compounds), or $\mathrm{Hg}$ may be bound to particulates $\left(\mathrm{Hg}_{\mathrm{p}}\right)$ (Lindberg et al. 2007). RGM and $\mathrm{Hg}_{\mathrm{p}}$ have relatively short atmospheric residence times and may be deposited within hours to weeks, while the tropospheric residence time for $\mathrm{Hg}^{\mathrm{O}}$ is between 6 months and 2 years (Schroeder and Munthe 1998). 
Wildfires and biomass burning are significant sources of $\mathrm{Hg}$ emissions to the atmosphere (Brunke et al. 2001; Engle et al. 2006; Friedli et al. 2001, 2003a, b; Harden et al. 2004; Veiga et al. 1994; Wiedinmyer and Friedli 2007). During a wildfire, $\mathrm{Hg}$ is primarily emitted from vegetation and soils in the form of $\mathrm{Hg}^{\mathrm{o}}$. In a smoke plume, most $\mathrm{Hg}$ $(>87 \%)$ is in the form of $\mathrm{Hg}^{\circ}$, while the remaining is bound to particulates $\left(\mathrm{Hg}_{\mathrm{p}}\right)$; however, the ratio between the two is fuel-dependent (Friedli et al. 2003a, b). Although $\mathrm{Hg}$ is released primarily as $\mathrm{Hg}^{\circ}$, increased $\mathrm{MeHg}$ levels have been observed in the vicinity following a wildfire. Caldwell et al. (2000) reported sediment $\mathrm{MeHg}$ levels peaked within 3 months after a wildfire (64-km downwind from the fire origin) due to increased storm runoff and transport of $\mathrm{Hg}$ and $\mathrm{MeHg}$, while Amirbahman et al. (2004) observed elevated $\mathrm{MeHg}$ levels in soils burned 45 years prior to $\mathrm{Hg}$ analysis, indicating soil changes following a fire (e.g., higher soil $\mathrm{pH}$ ) persisted for years. Fires also enhance productivity in lakes through deposition of nutrients (Spencer et al. 2003), which may increase MeHg levels in fish tissue by lengthening the food chain (Kelly et al. 2006), or nutrients may decrease MeHg biomagnification in fish tissue due to algal bloom dilution (Chen and Folt 2005; Pickhardt et al. 2005).

In southern California, March to October is considered the fire season; however, the length of the season is dependent on winter precipitation levels. A number of water bodies in this region are listed as impaired for $\mathrm{Hg}$ in water, sediments and/or fish tissue (USEPA 2008), although there are no coal burning power plants and few other atmospheric point sources of $\mathrm{Hg}$ within the air shed. In this semi-arid region, fires may be a significant source of Hg. Forest fires produce ash, which may contain heavy metals that are easily solubilized and may impair water quality (Plumlee et al. 2007). Soils coated with ash are more water repellent than unburned sediments, causing increased erosion and higher runoff (Onda et al. 2008; Shakesby and Doerr 2006). While the effect of fires on lake sedimentation and water chemistry has been well documented (Gresswell 1999; Malmon et al. 2007; Minshall et al. 1989; Spencer et al. 2003), the impact of wildfires on historical sediment $\mathrm{Hg}$ levels has not previously been investigated.

$\mathrm{Hg}$ levels and $\mathrm{Hg}$ accumulation rates in dated sediment cores from two lakes in the southern California area, located approximately 40-km apart, were compared (Fig. 1). Big Bear Lake is a popular lakeside resort located in the San Bernardino Mountains, and Crystal Lake is a remote camping site in the San Gabriel Mountains. Over the last century, wildfires were minimized or suppressed near Big Bear Lake, while fires regularly charred the forest near Crystal Lake. Hg chronologies from both sites were investigated to determine whether higher frequency and

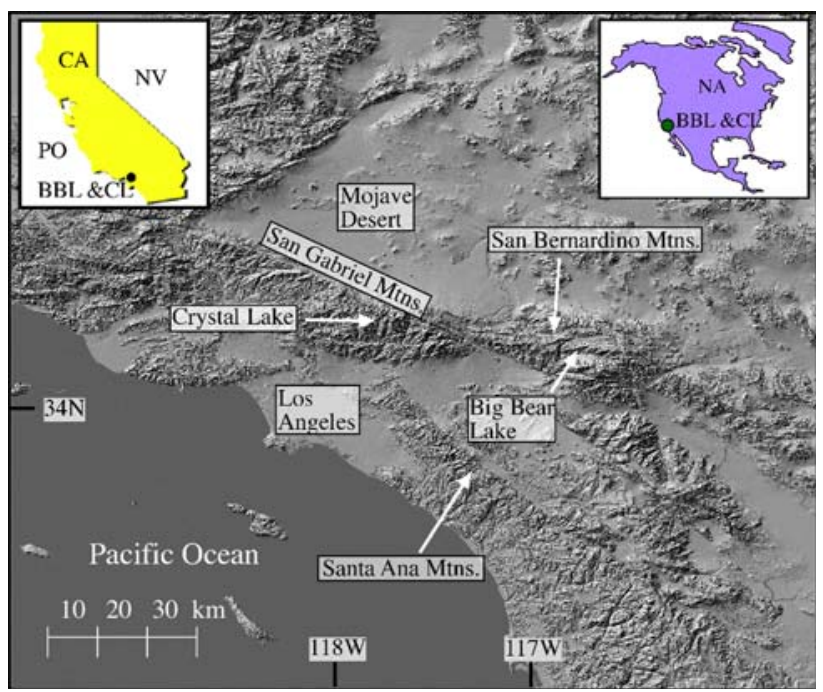

Fig. 1 Location of Crystal Lake (CL) and Big Bear Lake (BBL), where $\mathrm{CA}=$ California, $\mathrm{PO}=$ Pacific Ocean, $\mathrm{NV}=$ Nevada, and $\mathrm{NA}=$ North America

greater intensity of fires within the Crystal Lake watershed resulted in elevated $\mathrm{Hg}$ levels and higher $\mathrm{Hg}$ accumulation rates compared to Big Bear Lake.

\section{Methods}

Site descriptions and fire history

\section{Big Bear Lake, CA}

Big Bear Lake (elevation: 2,055 m) is located in the San Bernardino Mountains in the Santa Ana watershed (34.24 $\left.\mathrm{N}, 116.90^{\circ} \mathrm{W}\right)$. Lake levels are primarily dependent on precipitation (rain, snow) and evaporative processes. The surface area of the lake is $12 \mathrm{~km}^{2}$ and the watershed is $140 \mathrm{~km}^{2}$ (USDANRCS 1999). Average depth of Big Bear Lake is $7.3 \mathrm{~m}$, although near the dam the depth ranges from 15 to $22 \mathrm{~m}$. Big Bear Lake is moderately eutrophic, and during the summer months may exhibit severe oxygen depletion at depth (Siegfried et al. 1982). Big Bear Lake was first included on California's List of Water Quality Limited Segments for $\mathrm{Hg}$ in 1998 due to $\mathrm{Hg}$ levels $>0.3 \mathrm{ppm}$ in fish tissue (USEPA 2008), the recommended level for safe consumption (USEPA 2001).

Between 1895 (when fire history data were first available) and 2006, there were two large fires that burned $>25 \mathrm{~km}^{2}$ within $10 \mathrm{~km}$ of Big Bear Lake, one in 1970 (Bear Fire) and one in 1999 (Willow Fire) (Table 1a, USDAFS 2008). Additionally, 53 fires were recorded $<10 \mathrm{~km}$ from Big Bear Lake since 1895, although the developed area around Big Bear Lake was not burned (Fig. 2a, USDAFS 2008). 
Table 1 List of fires that burned more than $25 \mathrm{~km}^{2}$ and were $<10 \mathrm{~km}$ from each lake, 1895-2006

\begin{tabular}{|c|c|c|}
\hline Year & Name of fire & Area burned $\left(\mathrm{km}^{2}\right)$ \\
\hline \multicolumn{3}{|c|}{ a Big Bear Lake } \\
\hline 1970 & Bear & 209 \\
\hline 1999 & Willow & 257 \\
\hline 1895-2006 & $\begin{array}{l}51 \text { additional fires that } \\
\text { burned }<25 \mathrm{~km}^{2}\end{array}$ & 135 \\
\hline \multicolumn{2}{|c|}{$\begin{array}{l}\text { Total area burned }<10 \mathrm{~km} \text { from Big Bear Lake, } \\
1895-2006\end{array}$} & 601 \\
\hline \multicolumn{3}{|c|}{ b Crystal Lake } \\
\hline 1911 & Unnamed & 61 \\
\hline 1915 & Unnamed & 61 \\
\hline 1919 & San Gabriel & 221 \\
\hline 1924 & San Gabriel & 174 \\
\hline 1957 & Gale & 100 \\
\hline 1960 & Unnamed & 61 \\
\hline 1968 & Canyon Inn & 77 \\
\hline 1997 & Narrows & 73 \\
\hline 1999 & Bridge & 29 \\
\hline 2002 & Curve & 84 \\
\hline 2002 & Williams & 154 \\
\hline 1895-2006 & $\begin{array}{l}38 \text { additional fires that } \\
\text { burned }<25 \mathrm{~km}^{2}\end{array}$ & 66 \\
\hline \multicolumn{2}{|c|}{$\begin{array}{l}\text { Total area burned }<10 \mathrm{~km} \text { from Crystal Lake, } \\
\text { 1895-2006 }\end{array}$} & 1,162 \\
\hline
\end{tabular}

GIS fire data were obtained from the US Department of Agriculture Forest Service (USDAFS 2008)

Crystal Lake, CA

Crystal Lake (elevation: 1,657 m) is located within the Angeles National Forest at the headwaters of the San Gabriel River watershed $\left(34.19^{\circ} \mathrm{N}, 117.50^{\circ} \mathrm{W}\right)$, and is fed by primarily small springs and precipitation (rain, snow). Lake level is controlled by precipitation and evaporation. Several recently incised gullies revealed organic-rich, finegrained sediment, which may reflect past periods of sustained high lake levels. A well-defined tree line delineates the average historical high lake level position, which was substantially higher than the modern lake level. A recently felled tree near the tree line contains 160 rings, which provides a possible minimum age for the last episode of sustained lake level above the tree line. Aside from one event in the late 1800s when Crystal Lake was drained for agricultural purposes and then refilled (Conrad 2003), lake levels were not recorded.

Limnologically, the lake undergoes strong seasonal stratification and bottom water anoxia (depth $\sim 7 \mathrm{~m}$ ). Crystal Lake's surface area is $<0.023 \mathrm{~km}^{2}$ and the immediate drainage basin surrounding the lake is quite small $\left(\sim 0.50 \mathrm{~km}^{2}\right)$. Crystal Lake was first included on California's List of Water Quality Limited Segments in 1996 for



Fig. 2 Maps of fires in a Big Bear Lake and b Crystal Lake that charred $>25 \mathrm{~km}^{2}$ and were $<10 \mathrm{~km}$ from the perimeter of the lake, 1895-2006 (burned area in orange, with fire names superimposed). In Fig. 2b, Crystal Lake is represented by a yellow dot (near the Crystal Lake fire). GIS fire data were obtained from the US Forest Service (USDAFS 2008), and watershed boundaries (black line) were from CalWater Version 2.2.1 (USDANRCS 1999)

organic enrichment and low dissolved oxygen (USEPA 2008), but was not listed as impaired for $\mathrm{Hg}$. Although recreational fishing is a beneficial use for Crystal Lake (LARWQCB 1994), Hg levels in fish tissue are not monitored, most likely due to the relatively few number of visitors to the lake compared to other recreational sites (e.g., Big Bear Lake).

Unlike Big Bear Lake, which is populated by homes and small businesses, the immediate vicinity of Crystal Lake is surrounded by pine forest, and fires frequently engulf the area around Crystal Lake (Fig. 2b). Between 1895 and 2006, fires charred $1,160 \mathrm{~km}^{2}$ within $10 \mathrm{~km}$ from Crystal Lake (1.9 times the area burned neared Big Bear Lake) (USDAFS 2008). Compared to Big Bear Lake, more frequent, larger fires $\left(>25 \mathrm{~km}^{2}\right)$ occurred within $10 \mathrm{~km}$ of the lake (11 vs. 2) (Table 1). Of these 11 fires, severe fires $\left(>80 \mathrm{~km}^{2}\right)$ occurred in 1919 (East Fork San Gabriel River Fire), 1924 (San Gabriel Fire), 1957 (Gale Fire), and in 2002 (Curve Fire and Williams Fire; Fig. 2b; USDAFS 2008).

\section{Core extraction}

Table 2 includes a summary of sediment cores collected, including length, location, method of $\mathrm{Hg}$ analysis, the mean and range in sediment $\mathrm{Hg}$ levels and the number of slices 
Table 2 Length $(\mathrm{cm})$ and location for all sediment cores from Big Bear Lake and Crystal Lake, the method used for Hg analysis (EPA 7473 or EPA 1631), the mean and range in $\mathrm{Hg}$ levels $\left(\mathrm{ng} \mathrm{g}^{-1}\right)$, and sample size $(n)$

\begin{tabular}{|c|c|c|c|c|c|c|c|c|}
\hline \multirow[t]{2}{*}{ Site } & \multirow[t]{2}{*}{ Core } & \multirow[t]{2}{*}{ Length $(\mathrm{cm})$} & \multirow[t]{2}{*}{ Latitude } & \multirow[t]{2}{*}{ Longitude } & \multirow[t]{2}{*}{ EPA method } & \multicolumn{3}{|l|}{$\mathrm{Hg}$} \\
\hline & & & & & & Mean $\left(\operatorname{ng~g}^{-1}\right)$ & Range (ng g ${ }^{-1}$ ) & $n$ \\
\hline \multirow[t]{2}{*}{ Big Bear Lake } & BBL-1 & 51 & $\mathrm{~N} 34^{\circ} 14.42^{\prime}$ & W $116^{\circ} 57.56^{\prime}$ & 7473 & 92 & $13-130$ & 25 \\
\hline & BBL-2 & 34 & $\mathrm{~N} 34^{\circ} 14.60^{\prime}$ & W $116^{\circ} 55.09^{\prime}$ & 1631 & 78 & $47-95$ & 34 \\
\hline \multirow[t]{4}{*}{ Crystal Lake } & CL-1 & 69 & $\mathrm{~N} 34^{\circ} 19.11^{\prime}$ & W $117^{\circ} 50.84^{\prime}$ & 1631 & 220 & $57-510$ & 69 \\
\hline & & & & & 7473 & 210 & $48-370$ & 17 \\
\hline & CL-2 & 34 & $\mathrm{~N} 34^{\circ} 19.10^{\prime}$ & W $117^{\circ} 50.83^{\prime}$ & 7473 & 200 & $50-360$ & 22 \\
\hline & CL-4 & 45 & $\mathrm{~N} 34^{\circ} 19.12^{\prime}$ & W $117^{\circ} 50.83^{\prime}$ & NA & NA & NA & NA \\
\hline
\end{tabular}

$\mathrm{Hg}$ was not measured in CL-4 sediments (NA)

analyzed for $\mathrm{Hg}$. Cores were collected using a hand-driven piston corer (PC) or a gravity corer (GC).

\section{Big Bear Lake, CA}

Two cores, BBL-GC-2003-1, $(52 \mathrm{~cm}$, hereafter referred to as BBL-1) and BBL-GC-2002-2 $(34 \mathrm{~cm}$, hereafter referred to as BBL-2) were extracted from the western side of Big Bear Lake near the dam, the former in November 2003 and the latter in 2002. BBL-1 water depth was $11 \mathrm{~m}$, and BBL-2 water depth was $13 \mathrm{~m}$. BBL-2 sediments were freeze-dried, while BBL-1 sediments were archived in cold storage $\left(4^{\circ} \mathrm{C}\right)$. Analysis of $\mathrm{Hg}$ levels was completed in 2004 for the BBL-2 and in 2007 for BBL-1.

\section{Crystal Lake, CA}

In 2003, sediment cores were extracted from the lake's deepest basin $(6.4 \mathrm{~m})$, near three active gullies. Three cores (CL-PC-2003-01, CL-GC-2003-02, and CL-GC-2003-04 hereafter referred to as CL-1, CL-2 and CL-4, respectively) were opened, visually described and then archived in cold storage $\left(4^{\circ} \mathrm{C}\right)$ (Table 2). Hg was analyzed in CL-1 and CL-2 sediments in 2007, and CL-1 was re-analyzed in 2009. CL-4 is included in this analysis for illustrating the coherent stratigraphy across the lake basin.

Hg analysis

Except for core BBL-2, storage, splitting and slicing of sediment cores, as well as measurement of loss-on-ignition $550^{\circ} \mathrm{C}$ and $950^{\circ} \mathrm{C}$, grain size analysis, and selection of material for dating was completed at the Cal State Fullerton Paleoclimatology Lab (CA, USA). Core BBL-2 was sectioned and freeze-dried at the University of Southern California (CA, USA). Hg analysis for BBL-1, BBL-2, CL-1 (using EPA 7473), and CL-2 was completed at the University of California, Los Angeles (CA, USA), and Hg analysis of CL-1 (using EPA 1631) was completed at the
State Key Laboratory of Environmental Geochemistry (Guiyang, China).

Solid-phase $\mathrm{Hg}$ levels were determined in sediment slices using two methods: EPA Method 7473 (USEPA 1998) and EPA Method 1631 (USEPA 2002). Core BBL-2 was analyzed using EPA Method 1631, BBL-1 and CL-2 were analyzed using EPA Method 7473, and CL-1 was analyzed using both methods (Table 2). For both methods, standard trace metal protocols were followed.

\section{Method 1631}

Approximately $1 \mathrm{~g}$ of sediment was digested in acidcleaned vials overnight in $10 \mathrm{ml}$ of either $8: 2$ or $3: 1$ hydrochloric acid:nitric acid. Samples were oxidized with bromine monochloride, and excess oxidant was neutralized with hydroxylamine hydrochloride. Samples were further reduced with stannous chloride, converting $\mathrm{Hg}(\mathrm{II})$ to the more volatile $\mathrm{Hg}^{\mathrm{O}}$, which was purged from solution by argon gas. Quantification was by dual-stage gold amalgamation/cold vapor atomic fluorescence spectrometry (CVAFS). The oxidation-reduction steps follow established methods (Bloom and Crecelius 1983; Bloom and Fitzgerald 1988).

\section{Method 7473}

Sediments were measured using direct $\mathrm{Hg}$ analysis by thermal decomposition, amalgamation, and atomic absorption spectrophotometry. No pre-analysis steps were required.

\section{$H g$ resolution and $Q A / Q C$}

$\mathrm{Hg}$ was analyzed in 1-cm contiguous slices in core CL-1 using EPA 1631 and every 2-5 cm using EPA 7473 (Table 2). For the remainder of the paper, results from the former method were discussed, since more strata were analyzed and the correlation between $\mathrm{Hg}$ levels using the two methods was $0.78(n=17)$. For BBL-1 and BBL-2, a 
1-2 cm interval was analyzed, while every $2 \mathrm{~cm}$ were analyzed within CL-2 (Table 2).

The method detection level (MDL) was measured using $t *$ standard deviation of method blanks, where $t$ represented the level for specific $n$ at which there is $<1 \%$ chance of a Type 1 error, i.e., including a sample not significantly different from 0 (40 CFR, Appendix B to Part 136). For Method 1631 the MDL was $4.2 \mathrm{ng} \mathrm{g}^{-1}(n=6, t=3.365)$ and for Method 7473 the MDL was $4.7 \mathrm{ng} \mathrm{g}^{-1}(n=8$, $t=2.998$ ). MDLs for both methods were higher than values typically reported, most likely due to variability in $\mathrm{Hg}$ levels in beach sand (used as the matrix blank), which increased the standard deviation. For both methods, all measured $\mathrm{Hg}$ values in the sediment cores were greater than the MDL.

Recovery of standard reference material (IAEA-405 estuarine sediment, IAEA-433 marine sediment, GBW$07405)$ was $100 \pm 3.3 \%(n=26)$ for EPA 7473 , and for EPA 1631 recovery averaged $104 \pm 8.3 \%(n=8)$. For BBL-1 (EPA 1631), BBL-2 (EPA 1631), CL-2 (EPA 7473), and CL-1 (EPA 7473 only) all sediment slices for $\mathrm{Hg}$ were analyzed in triplicate. Reproducibility was measured using relative standard deviation (RSD, $100 \times \mathrm{sd} /$ mean) between triplicate measurements. For EPA 7473, RSD averaged $13 \pm 13 \%(n=64)$ and for EPA $1631 \mathrm{RSD}$ averaged $2.4 \pm 1.6 \%(n=33)$. A subset of CL-1 sediment slices (analyzed by EPA 1631) was measured in duplicate, and the relative percent difference (RPD) averaged $15 \pm 12 \%(n=6)$.

\section{Wet:dry ratio}

Wet sediments were dried overnight in a $60^{\circ} \mathrm{C}$ oven using pre-weighted crucibles, and the wet:dry ratio of the sample was determined. $\mathrm{Hg}$ concentrations are reported on a dry weight basis.

\section{Sedimentology}

All sedimentological parameters were analyzed at $1-\mathrm{cm}$ contiguous intervals.

\section{Mass magnetic susceptibility}

Mass magnetic susceptibility is a measure of the iron (Fe)bearing minerals within sediments, predominantly Fe oxides. Sediment samples were placed in $8-\mathrm{cm}^{3}$ plastic cubes, and mass magnetic susceptibility was measured twice on each sample with the $y$-axis rotated $180^{\circ}$ once per analysis, using a Bartington MS2 Magnetic Susceptibility instrument at $0.465 \mathrm{kHz}$. All magnetic susceptibility data were determined within $24 \mathrm{~h}$ of splitting the core in order to minimize oxidation effects.
Loss-on-ignition $550^{\circ}$ and $950^{\circ} \mathrm{C}$

Samples were combusted for $2 \mathrm{~h}$ at $550^{\circ} \mathrm{C}$ (total organic matter) and for an additional $2 \mathrm{~h}$ at $950^{\circ} \mathrm{C}$ (total carbonate); loss-on-ignition (LOI) was calculated after each heating (Dean 1974). For total carbonate, values $<3-4 \%$ may reflect clay de-watering, and hence were interpreted as $0 \%$ (Dean 1974).

\section{Microfossil analysis}

Analyses of microfossils (oogonia, the reproductive capsule of Chara) and charcoal were completed for Crystal Lake (CL-1). Prior to microfossil analyses, sediments (2-5 g) were disaggregated using $10 \%$ sodium hexametaphosphate. After 1-3 days, sediments were sieved $(250 \mu \mathrm{m})$, and remaining sediment was filtered, air-dried, and weighed. The sediments were split as required to reduce the total specimens for analysis. Using a standard binocular microscope, the number of charcoal pieces and oogonia were counted, corrected for splits and then normalized to the total number of specimens per $5 \mathrm{~g}$ of dry sediment.

\section{Bulk density}

Bulk density was determined by measuring the mass of wet or dry sediment in a known volume. For wet sediments, bulk density was converted to dry mass using percent water.

\section{Grain size analysis}

Grain size analysis was determined for cores BBL-1 and CL-1. Prior to grain size analysis, detrital material $>2,000 \mu \mathrm{m}$ was removed by wet sieving, and organic matter was volatilized using successive additions of $30 \%$ hydrogen peroxide $\left(\mathrm{H}_{2} \mathrm{O}_{2}\right)$ until no reaction occurred. Sands were split to achieve a desired obscuration of 3-5\%; clays and silts were split to achieve an obscuration of $8-14 \%$. Instrument accuracy and precision were verified daily and for every 10 samples using a tuff standard (TS2) with a known distribution between 1.00 and 16.0 (average $4.53 \mu \mathrm{m} \pm 0.07 ; n=2,998$ ). Two separate standard operating procedures were used for sands and clays/silts, both based on the Mie Scattering principle. Size distributions are reported as volume percent clay $(0.02 \mu \mathrm{m}$ to $3.89 \mu \mathrm{m})$, silt (3.90 $\mu \mathrm{m}$ to $73.9 \mu \mathrm{m})$, and sand $(74.0 \mu \mathrm{m}$ to $2,000 \mu \mathrm{m})$.

\section{Other metals}

For core BBL-1, bulk elemental composition was determined on 17 samples using a Phillips PW 2400 X-Ray Fluorescence (XRF) scanner at UC Berkeley (lead, zinc, 
iron, chromium, copper, nickel, vanadium, and aluminum). Samples were dried, ground, treated with a bonding agent, and compressed into pellets.

\section{Age control}

Age control for Big Bear (BBL-1) and Crystal Lake (CL1) cores was determined using (1) surface sediment age based on an intact sediment-water interface (BBL-1 and CL-1), (2) ${ }^{137} \mathrm{Cs}$ analyses (BBL-1 and CL-1), (3) elemental $\mathrm{Pb}$ concentrations (core BBL-1 only), and (4) ${ }^{210} \mathrm{~Pb}$ analyses (core CL-1 only). Analysis for ${ }^{210} \mathrm{~Pb}$ is used to date young ( $<200$ year) sediments (Appleby and Oldfield 1978; Crusius and Anderson 1995; Krishnaswami et al. 1971), while ${ }^{137} \mathrm{Cs}$ is used to determine the year (1963) for maximum nuclear fallout from weapons testing (Robbins and Edgington 1975), as well as the year when ${ }^{137} \mathrm{Cs}$ first appeared in measurable levels in environmental samples (1954) (Ritchie and McHenry 1990). For ${ }^{137} \mathrm{Cs}$, $2-6 \mathrm{~g}$ of sediment were sealed in $60 \times 15 \mathrm{~mm}$ plastic petri dishes, aged for 30 days and counted on a gamma spectrometer (Hyperpure Ge detector) for the determination of ${ }^{137} \mathrm{Cs}$ and ${ }^{226} \mathrm{Ra}$. ${ }^{226} \mathrm{Ra}$ was also analyzed on selected slices by the radon de-emanation technique (Mathieu 1997; Wilkinson 1985). For ${ }^{210} \mathrm{~Pb}$, 1-g samples were leached in $6 \mathrm{~N} \mathrm{HCl}$ in the presence of a ${ }^{209} \mathrm{Po}$. Po was autoplated onto a silver disc (Flynn 1968) and counted on an alpha spectrometer to determine ${ }^{210} \mathrm{~Pb}$ via its ${ }^{210} \mathrm{Po}$ daughter, and excess ${ }^{210} \mathrm{~Pb}$ was determined in each slice by subtracting the ${ }^{226} \mathrm{Ra}$ activity. For core BBL-1, a peak in elemental $\mathrm{Pb}$, measured using XRF (described in "Sedimentology"), was used as an age based on the removal of lead from gasoline in the 1970s (1975 \pm 5 year) (Callender and Rice 2000).

$\mathrm{Hg}$ accumulation rates

$\mathrm{Hg}$ accumulation rates (i.e., $\mathrm{Hg}$ fluxes) were estimated using the following equation:

$F=C_{\mathrm{Hg}} \times \rho_{\text {sed }} \times S R \times 10$

where $F$ is the $\mathrm{Hg}$ flux $\left(\mu \mathrm{g} \mathrm{m}^{-2}\right.$ year $\left.^{-1}\right) ; C_{\mathrm{Hg}}$ is the concentration of $\mathrm{Hg}$ in sediments $\left(\mathrm{ng} \mathrm{g}^{-1}\right) ; \rho_{\text {sed }}$ is the sediment dry bulk density $\left(\mathrm{g} \mathrm{cm}^{-3}\right) ; S R$ is the sediment accumulation rate $\left(\mathrm{cm}\right.$ year $\left.{ }^{-1}\right)$.

\section{Results and discussion}

Core descriptions and age control

\section{Big Bear Lake}

Big Bear Lake sediments (BBL-1) were characterized as black, water-rich clayey silt from the top of the core to $25 \mathrm{~cm}$. From 25 to $34 \mathrm{~cm}$, sediments were black-gray to gray-black clayey silt, changing to an organic-rich clay silt between 46 and $50 \mathrm{~cm}$. Between 47 and $50 \mathrm{~cm}$, percent sand increased sharply from 9.0 to $82 \%$. On average, the clay fraction comprised $17 \%$ of the grain size distribution, while silt and sand comprised $75 \%$ and $7.8 \%$, respectively (Fig. 3).

BBL-1 surface sediments were dated as 2003, the year the core was extracted (see Fig. 3d); a peak in elemental $\mathrm{Pb}$ at $30 \mathrm{~cm}$ was assigned an age of $1975 \pm 5$ year; a peak in

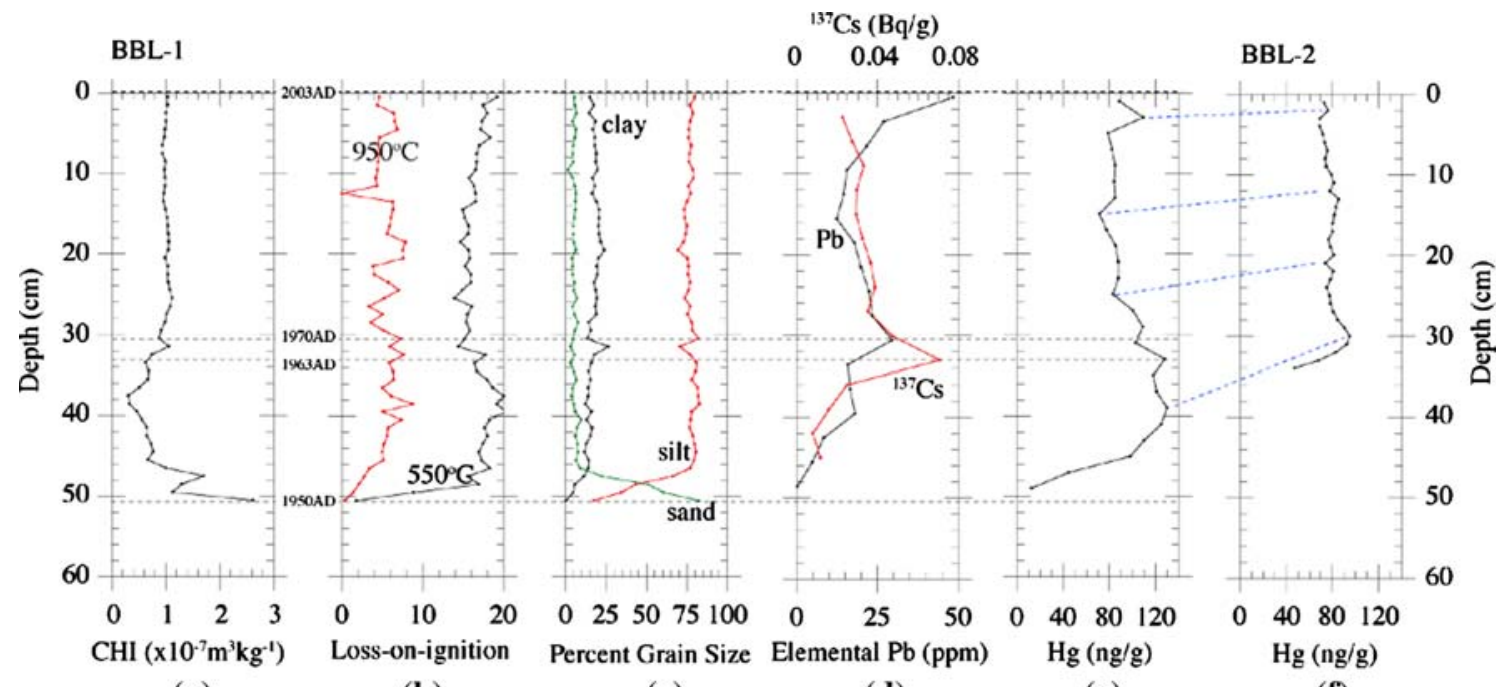

(a)

(b)

(c)

(d)

(e)

(f)

Fig. 3 Depth (cm) versus sedimentological and geochemical parameters for Big Bear Lake (BBL-1): $a$ Mass magnetic susceptibility $\left(\mathrm{CHI} \times 10^{-7} \mathrm{~m}^{3} \mathrm{~kg}^{-1}\right), b$ total organic matter (LOI, 550 ${ }^{\circ} \mathrm{C}$ ) and total

carbonate (LOI $950^{\circ} \mathrm{C}$, red line), $c$ particle size (\% sand, silt, and clay), $d{ }^{137} \mathrm{Cs}\left(\mathrm{Bq} \mathrm{g}^{-1}\right)$ and total $\mathrm{Pb}$ (ppm, red line), $e$ BBL-1 $\mathrm{Hg}$ $\left(\mathrm{ng} \mathrm{g}^{-1}\right), f$ BBL-2 $\mathrm{Hg}\left(\mathrm{ng} \mathrm{g}^{-1}\right)$ 
${ }^{137} \mathrm{Cs}$ at $31 \mathrm{~cm}$ was assigned the date 1963; between $45 \mathrm{~cm}$ and the base of the core, ${ }^{137} \mathrm{Cs}$ was no longer measurable and represented sediment deposited before 1954; the bottom of the core $(50 \mathrm{~cm})$ was inferred as $\sim 1950 \mathrm{~s} \pm 5$ year, corresponding to a decrease in lake level. Between 1946 and 1951 , lake level recorded near the dam decreased from 19 to $10 \mathrm{~m}$, the lowest level recorded since 1904, which was due to a prolonged period of below average precipitation levels ( $\sim 20$ year) and heavy irrigation demands (BBMWD 2008). Between 1951 and 1961, lake level averaged $13 \mathrm{~m}$. In the 1960s, lake level increased from 10 to $21 \mathrm{~m}$, and between 1969 and 2004 lake level averaged $19 \mathrm{~m}$. The basal age for core BBL-1 ( 1950s \pm 5 year $)$ was based on a sharp increase in sand (from $9.0 \%$ to $82 \%$ ), which represented an encroachment of the littoral zone into the deep basin during the low stand, or the rapid influx of sediment as lake level rose following the low stand (Fig. 3c). Likewise, the bottom of BBL-2 $(34 \mathrm{~cm})$ was assigned a date of $1950 \mathrm{~s} \pm 5$ years due to the steep increase in sand, similar to core BBL-1. In 1964 the Big Bear Water District was formed to regulate water dissemination from the lake, and in 1977 irrigation withdraws were halted (BBMWD 2008).

\section{Crystal Lake}

Cores CL-1, CL-2, and CL-4 were opened and visually described. All three cores were characterized by similar lithologies, and there was a strong correlation between LOI $550^{\circ} \mathrm{C}$, LOI $950^{\circ} \mathrm{C}$, and several sedimentologically distinct layers (discussed below) (Fig. $4 \mathrm{a}-\mathrm{c}$ ). Age control was determined for CL-1, the longest core $(69 \mathrm{~cm})$.
Core CL-1 was dominated throughout by a silty sand except from 2 to $7 \mathrm{~cm}$ and $57 \mathrm{~cm}$ to $69 \mathrm{~cm}$, where sand was the dominant grain size. On average, clay accounted for $7.7 \%$ of the grain size distribution, while silt and sand accounted for $54 \%$ and $38 \%$ of the distribution, respectively. The sediment color was highly varied from light gray to dark brown; the core section between 14 and $38 \mathrm{~cm}$ was characterized by faint laminations.

CL-1 was interspersed with visually distinct sediment layers (color changed from light to dark brown), which were characterized by a sharp basal contact and an abrupt increase in one or more of the following: magnetic susceptibility, organic matter, charcoal levels, or the shells of oogonia. In addition, percent sand increased at the base or very near the base of each sediment layer (Fig. 4a-g). Similar layers were observed in cores CL-2 and $\mathrm{Cl}-4$ (Fig. 5). Within CL-1 there were six layers $(5-15,24-28,31-34,38-43,51-55$, and 59-63 cm), three layers were observed in core CL-2 (4.5-9.5, 15-20, and $27-31 \mathrm{~cm})$, and four were observed in core CL-4 (0-10, 22-28, 30-34, and 39-45 cm) (Fig. 5). These layers are referred to rapidly deposited layers (RDLs, i.e., turbidites), and are typically associated with floods, earthquakes, and terrestrial landslides, i.e., events that trigger higher sediment loads (Bird and Kirby 2006; Brown et al. 2002; Noda et al. 2008; Rodbell et al. 1999; St-Onge et al. 2004).

For core CL-1, the age of the intact sediment-water interface was assumed to be 2003, when the core was extracted. A peak in ${ }^{137} \mathrm{Cs}$ occurred at $20.5 \mathrm{~cm}$ and was assigned 1963 (Fig. 4d). Using ${ }^{210} \mathrm{~Pb}$ values, the depth-age



(a) (b)

\section{Oogonia Charcoal
$5 \mathrm{~g}$ dry sediment $)$}

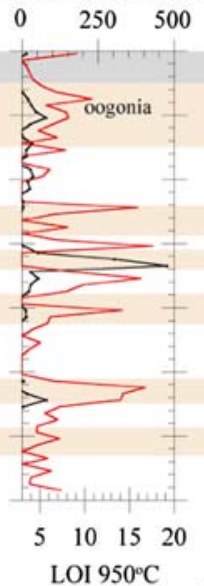

(c)

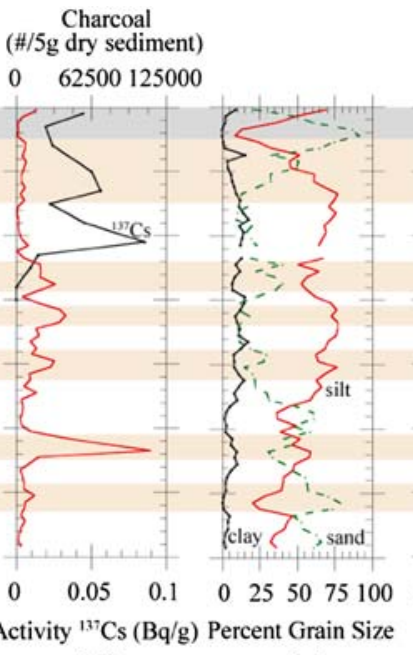

(d) (e)

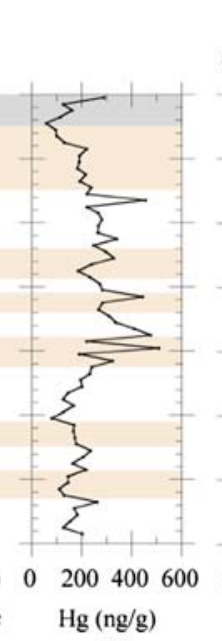

(f)



(g)
Fig. 4 Depth $(\mathrm{cm})$ versus sedimentological and geochemical parameters for Crystal Lake (CL-1): a Mass magnetic susceptibility $\left(\mathrm{CHI} \times 10^{-7} \mathrm{~m}^{3} \mathrm{~kg}^{-1}\right), b$ total organic matter (LOI $550^{\circ} \mathrm{C}$ ) and excess ${ }^{210} \mathrm{~Pb}\left(\mathrm{~Bq} \mathrm{~g}^{-1}\right.$, red line $), c$ total carbonate $\left(\mathrm{LOI} 950^{\circ} \mathrm{C}\right)$ and oogonia (\# $(5 \mathrm{~g})^{-1}$, red line $), d$ charcoal $\left(\#(5 \mathrm{~g})^{-1}\right.$, red line $)$ and
${ }^{137} \mathrm{Cs}\left(\mathrm{Bq} \mathrm{g}{ }^{-1}\right), e$ particle size (\% sand, silt, and clay), $f \mathrm{Hg}\left(\mathrm{ng} \mathrm{g}^{-1}\right)$, $g$ for CL-2, $\mathrm{Hg}$ (ng g ${ }^{-1}$, black line) and total organic matter (LOI $550^{\circ} \mathrm{C}$ ). Rapidly deposited layers (RDLs) are indicated by bars (for CL-1, $n=6$ layers; for CL-2, $n=3$ layers) 
Fig. 5 Depth $(\mathrm{cm})$ versus total organic matter $\left(\mathrm{LOI} 550^{\circ} \mathrm{C}\right.$, black lines) and total carbonate (LOI $950^{\circ} \mathrm{C}$, red lines) for cores CL-1, CL-2, and CL-4 of Crystal Lake. Brown bars correspond to rapidly deposited layers (RDLs), and dashed lines show potential tie points between cores

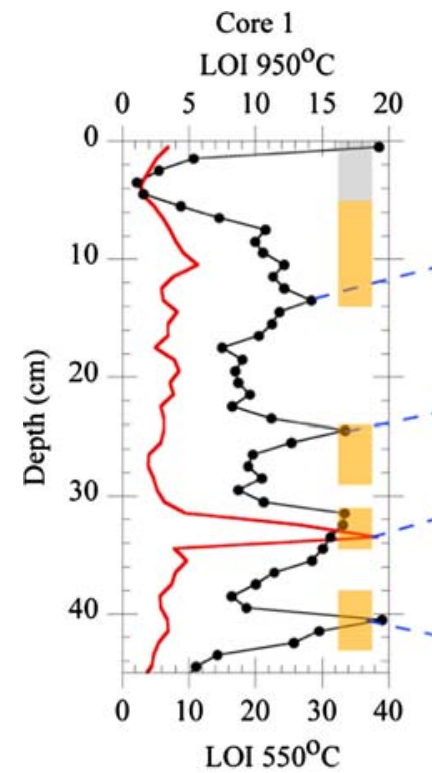

(a)

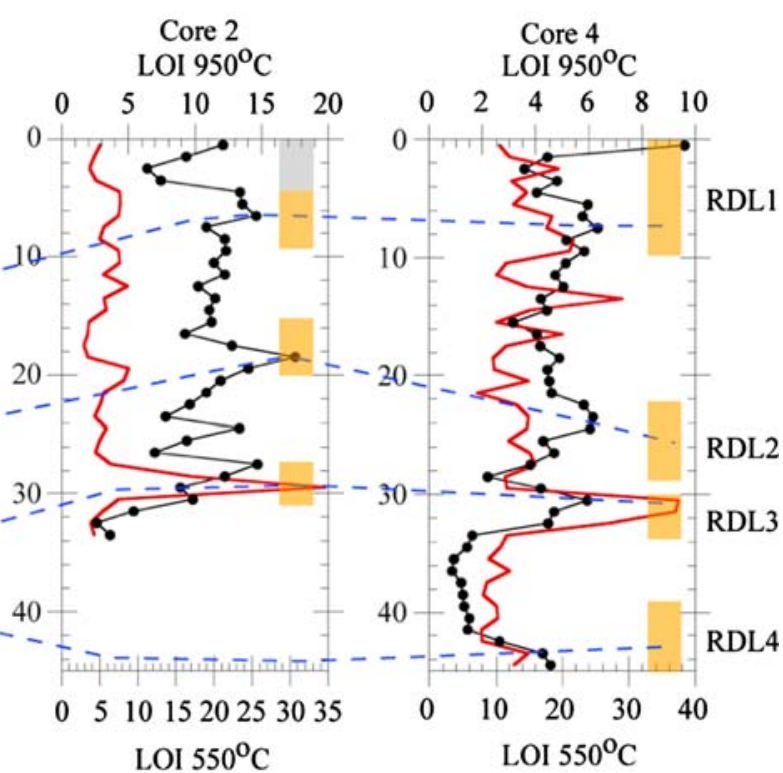

(b)

(c) profile was calculated using the constant rate of supply (CRS, Appleby and Oldfield 1978; Appleby 2001). The CRS model assumes the sediment transport parameters are independent of the sedimentation rate and there is a constant influx of unsupported ${ }^{210} \mathrm{~Pb}$ to the sediments. This model is used when the sedimentation rate is constant, although it may be appropriate in sites with non-uniform accumulation if results compare with other dating methods (Appleby 2001).

${ }^{210} \mathrm{~Pb}$ activities were low in the upper $3 \mathrm{~cm}$ of the core, increased by $4 \mathrm{~cm}$, and subsequently declined exponentially to the bottom of the core, although with some variability (discussed below). Application of the CRS model accurately estimated the age of the ${ }^{137} \mathrm{Cs}$ peak within 2 years (1961). Excluding turbidite layers, the sedimentation rate, which was estimated from the mean depth of the $1963{ }^{137} \mathrm{Cs}$ peak, was $0.29 \mathrm{~cm} \mathrm{year}^{-1}$, while the sedimentation rate from the ${ }^{210} \mathrm{~Pb}$ age model was $0.73 \mathrm{~cm}$ year $^{-1}(1837-2003)$. If the values from 1 to $3 \mathrm{~cm}$ were excluded for the latter calculation, the sedimentation rate was $0.30 \mathrm{~cm}_{\text {year }}{ }^{-1}(1837-1971)$. From the ${ }^{210} \mathrm{~Pb}$ model, $57 \mathrm{~cm}$ corresponded to 1837; the basal age (at $69 \mathrm{~cm}$ ) could not be accurately estimated without an independent chronostratigraphic marker.

Variability in the decline of ${ }^{210} \mathrm{~Pb}$ values indicated major episodes of rapid sedimentation at $3 \mathrm{~cm}$ (dated $\sim 2001$ ), 20-28 cm (dated $\sim 1950$, corresponding to RDL2), and $47-54 \mathrm{~cm}$ (dated $\sim 1870$, corresponding to RDL-5) (Fig. 6). Higher ${ }^{210} \mathrm{~Pb}$ values due to the emplacement of RDL-3 $(31-34 \mathrm{~cm})$ and RDL-4 $(38-43 \mathrm{~cm})$ were not observed, and RDL-6 $(59-63 \mathrm{~cm})$ occurred below the section of the core, where ${ }^{210} \mathrm{~Pb}$ was measurable. An unusual feature of the core was the very high ${ }^{210} \mathrm{~Pb}$ supply

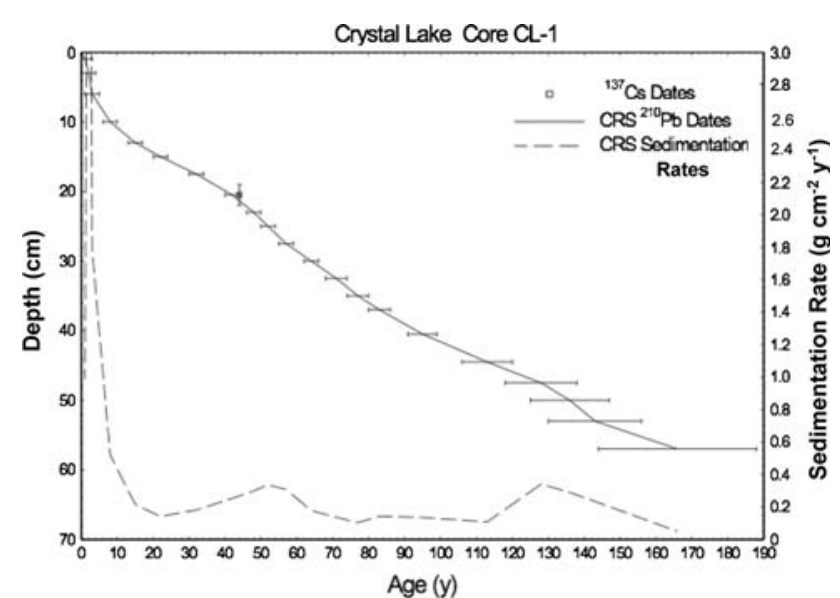

Fig. 6 For Crystal Lake core CL-1, depth (cm) versus age (y) \pm 1 standard deviation (solid line), and the sedimentation rate $\left(\mathrm{g} \mathrm{cm}^{-2} \mathrm{y}^{-1}\right)$ versus age (y) (dashed line). Age was calculated from the ${ }^{210} \mathrm{~Pb}$ age model, and based on a constant rate of supply (CRS)

rate (or flux) of $625 \mathrm{~Bq} \mathrm{~m}^{-2}$ year $^{-1}$. This suggested that CL-1 was from a site subjected to fairly intense sediment focusing (Peter Appleby, personal communication).

Dates for rapidly deposited layers (RDLs)

RDLs represent instantaneous depositional events, and were assigned the date of the top contact age minus one year, \pm 1 standard deviation (calculated from the ${ }^{210} \mathrm{~Pb}$ age model); i.e., $2000 \pm 2$ (5-15 cm, RDL-1), $1954 \pm 2$ (24$28 \mathrm{~cm}, \mathrm{RDL}-2), 1938 \pm 2$ (31-34 cm, RDL-3), $1919 \pm 3$ (38-43 cm, RDL-4), and $1866 \pm 11(51-55 \mathrm{~cm}$, RDL-5) (Table 3). A date for RDL-6 $(59-63 \mathrm{~cm})$ was not assigned, 
Table 3 Within Crystal Lake, comparison between dates for rapidly deposited layers (RDLs, i.e., turbidites) estimated from the ${ }^{210} \mathrm{~Pb}$ age model \pm 1 standard deviation (sd), and historical events within the lake's drainage basin, including fire history in the last century (USDAFS 2008), store construction (Conrad 2003), and the 1878 unnamed fire (Minnich 1987, Goforth and Minnich, 2007)

\begin{tabular}{llll}
\hline RDL \# & $\begin{array}{l}\text { Depth } \\
(\mathrm{cm})\end{array}$ & $\begin{array}{l}\text { Estimated } \\
\text { date } \pm 1 \text { sd }\end{array}$ & $\begin{array}{l}\text { Events within } \\
\text { the drainage basin }\end{array}$ \\
\hline 1 & $5-15$ & $2000 \pm 2$ & 2002 Curve Fire \\
2 & $24-28$ & $1954 \pm 2$ & 1957 Gale Fire \\
3 & $31-34$ & $1938 \pm 2$ & 1930s store construction \\
4 & $38-43$ & $1919 \pm 3$ & 1919 San Gabriel River Fire \\
5 & $51-55$ & $1866 \pm 11$ & 1878 unnamed fire \\
6 & $59-63$ & NA & NA \\
\hline
\end{tabular}

RDL-6 was not dated, since it occurred below the section of the core, where ${ }^{210} \mathrm{~Pb}$ values were measurable

since this section of core was deposited below measurable levels for ${ }^{210} \mathrm{~Pb}$, as indicated in the previous section.

Dates for RDLs-1, 2, 4 corresponded closely to known dates for fires (Table 3), which burned $>25 \mathrm{~km}^{2}$ within the immediate vicinity of the lake's drainage basin (RDL-1: 2002 Curve Fire, RDL-2: 1957 Gale Fire, RDL-4: 1919 San Gabriel River Fire, fire history from USDAFS 2008). Within RDL-5 (1866 \pm 11 year), high charcoal counts suggested fallout from an unnamed fire in 1878 (see Fig. 4d), which was one of the largest and longest fires in the Angeles National Forest $\left(240 \mathrm{~km}^{2}\right.$, burned all summer), and occurred within $20 \mathrm{~km}$ of Crystal Lake (Minnich 1987; USDAFS 2008). It is possible the perimeter of the fire was closer to the lake, as the location and area burned were not accurately recorded at the time of the fire; more precise record keeping did not begin until the instigation of fire suppression management in 1895 (Goforth and Minnich 2007). RDL-3 (1938) was the only sediment layer not associated with a fire; however, a spike in total carbonate $\left(32-34 \mathrm{~cm}\right.$, LOI, $950^{\circ} \mathrm{C}>18 \%$, Fig. $\left.4 \mathrm{c}\right)$ suggested the RDL occurred following the 1930s construction of a lakeside store (Conrad 2003), during which cement (i.e., calcium carbonate, $\mathrm{Ca}\left(\mathrm{CO}_{3}\right)$ ) was likely deposited into the lake.

The correspondence between the sedimentological record and known historical events suggested the age model for Crystal Lake may be appropriate.

\section{Diagenetic remobilization}

Diagenetic remobilization of $\mathrm{Hg}$ in core BBL-1 was investigated by comparing $\mathrm{Fe}, \mathrm{Al}$, and $\mathrm{Hg}$ levels. Additional metals (e.g., $\mathrm{Fe}, \mathrm{Al}$ ) were not measured for the Crystal Lake cores (CL-1, 2, 4). Previous work indicated $\mathrm{Hg}$ chronologies may be confounded by biological reworking of sediments and sorption of $\mathrm{Hg}$ onto redox sensitive metals, such as Fe (Rasmussen 1994). However, Lockhart et al. (2000) analyzed $\mathrm{Hg}$ in sediment cores from polluted sites and verified sediment total mercury profiles were stable over time, while Rydberg et al. (2008) reported diagenesis did not significantly obfuscate $\mathrm{Hg}$ trends in sediment cores over a 30 -year period. In core BBL-1, there was a lack of correlation between $\mathrm{Fe}$ and $\mathrm{Hg}$ levels $\left(r^{2}=0.00, p>0.95, n=8\right)$, while there was a strong correlation between $\mathrm{Al}$ and Fe levels $\left(r^{2}=0.88, p<0.01\right.$, $n=17$ ), suggesting a low probability that diagenetic remobilization impacted $\mathrm{Hg}$ levels.

Hg chronologies and accumulation rates

\section{Big Bear Lake}

$\mathrm{Hg}$ concentrations for Big Bear Lake cores ranged from 13 to $130 \mathrm{ng} \mathrm{g}^{-1}$ (core BBL-1) and from 47 to $95 \mathrm{ng} \mathrm{g}^{-1}$ (core BBL-2) (Fig. 3e-f). Hg and organic content were more strongly correlated in BBL-1 $\left(r^{2}=0.56, p<0.01\right)$ compared to BBL-2 $\left(r^{2}=0.01, p>0.50\right)$, although at the base of the core the two parameters were more positively correlated (26-33 cm, $\left.r^{2}=0.56, p<0.05\right)$. Despite these differences, the overall trend in $\mathrm{Hg}$ concentrations was similar between the two cores, i.e., highest $\mathrm{Hg}$ levels were observed at near the base of the core (1950s). Hg accumulation rates for BBL-1 ranged from 110 to $320 \mu \mathrm{g} \mathrm{m}^{-1}$ year $^{-1}$ and were highest in the 1950s and 1960s (Fig. 7a).

One explanation for the $\mathrm{Hg}$ pulse near the base of the core concerned changes in particle size distribution. Increased concentrations of heavy metals are associated with the smaller size fraction (i.e., silt or clay) due to greater sorption capacity (Bengtsson and Picado 2008; Fukue et al. 2006; Schuster 1991). In BBL-1, minimum $\mathrm{Hg}$ concentrations occurred at $52 \mathrm{~cm}$ (the base of core BBL-1), where sand, silt, and clay comprised 82, 17, and $<1 \%$, respectively. At $45 \mathrm{~cm}, \mathrm{Hg}$ concentrations were $98 \mathrm{ng} \mathrm{g}^{-1}$ (i.e., a 7.5-fold increase) and the distribution of sand, silt, and clay was $7.6,81$, and $12 \%$, respectively. $\mathrm{Hg}$ concentrations were positively correlated with the silt and clay fractions, while negatively correlated with sand $\left(r^{2}=0.52, p<0.01\right)$. Changes in particle size reflected a rapid increase in lake level beginning in the 1960s; as lake levels rose, heavier sediment particles were not easily transported to the deeper area of the lake. Based on the age model, the sedimentation rate between 1950 and mid-1960s $(32-52 \mathrm{~cm})$ was 1.4 times greater compared to the mid-1960s to the present $(0-31 \mathrm{~cm})\left(1.5 \mathrm{~cm}_{\text {year }}{ }^{-1}\right.$ vs. $\left.1.1 \mathrm{~cm} \mathrm{year}^{-1}\right)$, indicating rapid accumulation of finer grain particles as lake levels increased, which led to increased $\mathrm{Hg}$ concentrations. 

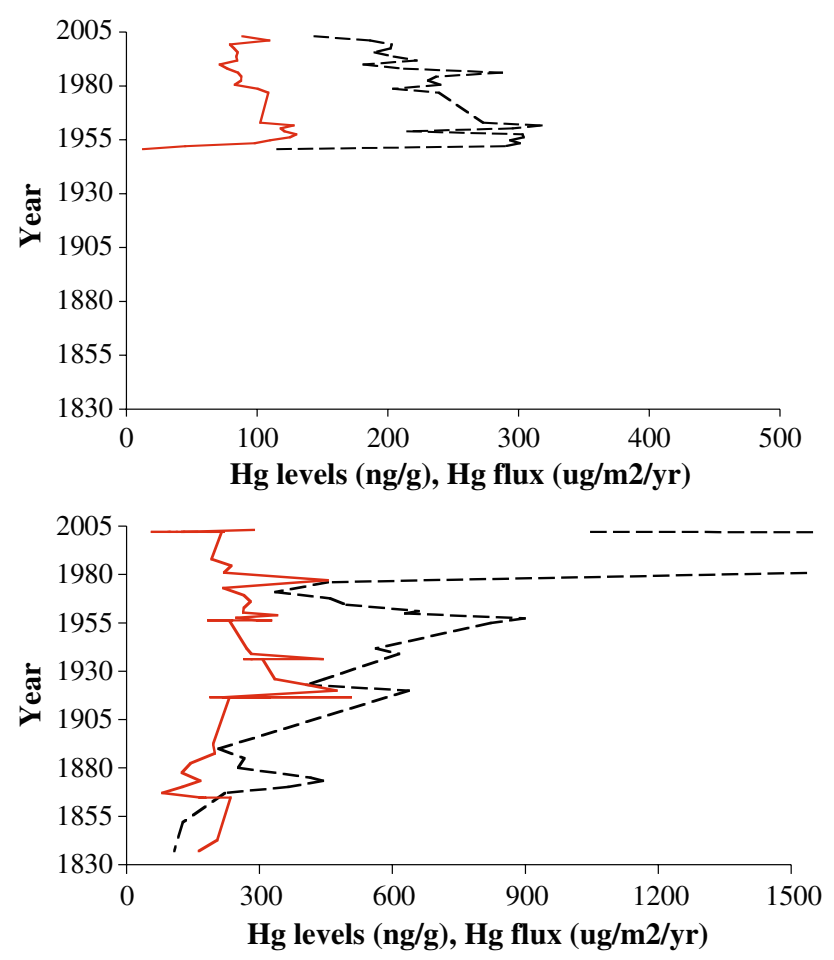

Fig. 7 a Year versus $\mathrm{Hg}$ concentrations $\left(\mathrm{ng} \mathrm{g}^{-1}\right.$, red line $)$ and $\mathrm{Hg}$ accumulation rates $\left(\mu \mathrm{g} \mathrm{m}^{-2}\right.$ year $^{-1}$, black dotted line $)$ for BBL-1. b Year versus $\mathrm{Hg}$ concentrations ( $\mathrm{ng}^{-1}$, red line) and $\mathrm{Hg}$ accumulation rates $\left(\mu \mathrm{g} \mathrm{m}^{-2}\right.$ year $^{-1}$, black dotted line) for CL-1. For the latter, the maximum value was $6,000 \mu \mathrm{g} \mathrm{m}^{-2}$ year $^{-1}$ (not included on the graph). Hg flux was not calculated for rapidly deposited layers (RDLs), which occurred at the following dates: $2000 \pm 2(5-15 \mathrm{~cm}$, RDL-1), $1954 \pm 2$ (24-28 cm, RDL-2), $1938 \pm 2$ (31-34 cm, RDL$3), 1919 \pm 3$ (38-43 cm, RDL-4), and $1866 \pm 11$ (51-55 cm, RDL5). A date for RDL-6 $(59-63 \mathrm{~cm})$ was not assigned, since this section of the core was deposited below measurable levels for ${ }^{210} \mathrm{~Pb}$, which were used to date the core

Two large fires occurred $<10 \mathrm{~km}$ from Big Bear Lake, (1970 Bear Fire, 1999 Willow Fire) (Table 1a; USDAFS 2008). There was a spike in Hg levels near the top of the core (Fig. 3e-f, 2003 for BBL-1, 2002 for BBL-2), which may be associated with the 1999 fire. There was no $\mathrm{Hg}$ spike associated with the 1970 fire, although this was a large fire $\left(209 \mathrm{~km}^{2}\right)$ and occurred closest to the western edge of Big Bear.

\section{Crystal Lake}

$\mathrm{Hg}$ levels for Crystal Lake sediments ranged from 57 to $510 \mathrm{ng} \mathrm{g}^{-1}$ (CL-1) and from 50 to $360 \mathrm{ng} \mathrm{g}^{-1}$ (CL-2) (Fig. 5f-g). Within CL-1, Hg levels did not increase monotonically; minimum $\mathrm{Hg}$ concentrations $\left(<100 \mathrm{ng} \mathrm{g}^{-1}\right)$ occurred at the base of the core (pre-1867) and near the top of the core (2002). Several spikes in Hg concentrations (400$500 \mathrm{ng} \mathrm{g}^{-1}$ ) were observed at the following dates: 1916, 1920, 1923, 1936, and 1977, and somewhat higher Hg levels occurred in $1956\left(330 \mathrm{ng} \mathrm{g}^{-1}\right)$ and $2003\left(290 \mathrm{ng} \mathrm{g}^{-1}\right) . \mathrm{Hg}$ accumulation rates were calculated for non-RDL layers, since RDLs were deposited instantaneously; only those fluxes during periods of "normal" accumulation were significant (Peter Appleby, personal communication). $\mathrm{Hg}$ accumulation rates ranged from 110 to $6,000 \mu \mathrm{g} \mathrm{m}^{-2}$ year $^{-1}$; highest rates occurred in $\sim 2002$, when sedimentation rates sharply increased (Fig. 6). Compared to Big Bear Lake, average $\mathrm{Hg}$ levels in Crystal Lake sediments were nearly 2.5 times higher than Big Bear Lake sediments (CL-1: $220 \pm 93 \mathrm{ng} \mathrm{g}^{-1}$, CL-2: $200 \pm 85 \mathrm{ng} \mathrm{g}^{-1}$, BBL-1: $92 \pm$ $26 \mathrm{ng} \mathrm{g}^{-1}$, and BBL-2: $78 \pm 8.2 \mathrm{ng} \mathrm{g}^{-1}$ ), and average $\mathrm{Hg}$ accumulation rates at Crystal Lake were 3.3 times higher than Big Bear Lake accumulation rates (CL-1: $790 \pm$ $1200 \mu \mathrm{g} \mathrm{m}^{-2}$ year $^{-1}$, BBL-1: $240 \pm 54 \mu \mathrm{g} \mathrm{m}^{-2}$ year $^{-1}$ ). Within CL-1, Hg and organic content were positively correlated $\left(r^{2}=0.27, p<0.01\right)$, but were not correlated within CL-2 sediments $\left(r^{2}=0.07, p>0.20\right)$.

In California (USA), three other sediment core studies reported enrichment of $\mathrm{Hg}$ since the pre-industrial period, including sediments within 4 pristine lakes located throughout California (from Sanders et al. 2008), Lake Tahoe (from Heyvaert et al. 2000), and the San Francisco Bay (from Hornberger et al. 1999). Compared to Crystal Lake, results from these studies indicated background levels (i.e., pre-industrial) were lower and enrichment factors were higher, and for most sites, maximum $\mathrm{Hg}$ levels in Crystal Lake exceeded those previously reported (Table 4). In Crystal Lake, the ratio between pre-industrial (pre-1865, range: $110-260 \mathrm{ng} \mathrm{g}^{-1}$ ) and modern (post1965, range: $57-450 \mathrm{ng} \mathrm{g}^{-1}$ ) $\mathrm{Hg}$ concentrations was 1.1, and several spikes in $\mathrm{Hg}$ levels occurred between 1910 and 1985. Given the remote location of the lake, the proximity of fires, and the lack of other $\mathrm{Hg}$ sources within the area, these results suggested wildfires (rather than industrial sources) were a continuous source of $\mathrm{Hg}$ to Crystal Lake over the last 150 years.

Modern and pre-industrial $\mathrm{Hg}$ accumulation rates were also compared; however far fewer data were available since flux was not calculated for RDLs, which comprised $36 \mathrm{~cm}$ of the $69 \mathrm{~cm}$ core, and there was no age control for the lower $12 \mathrm{~cm}$ of the core. $\mathrm{Hg}$ accumulation rates averaged $280 \mu \mathrm{g} \mathrm{m}^{-2}$ year $^{-1}$ prior to 1865 , while modern accumulation rates (post 1965) averaged $1,900 \mu \mathrm{g} \mathrm{m}^{-2}$ year $^{-1}$ (16 times higher). The latter result was strongly influenced by higher sedimentation flux near the top of the core (1-3 cm, Fig. 7b).

Atmospheric deposition of $\mathrm{Hg}_{\mathrm{p}}$

$\mathrm{Hg}$ levels in soils typically decrease following a fire (Amirbahman et al. 2004; Biswas et al. 2007; DiCosty et al. 2006; Engle et al. 2006; Friedli et al. 2001; Harden 
Table 4 Comparison between pre-industrial and modern $\mathrm{Hg}$ levels $\left(\mathrm{ng} \mathrm{g}^{-1}\right)$ in California (CA) water bodies

\begin{tabular}{|c|c|c|c|}
\hline Lake & $\begin{array}{l}\text { Pre-industrial } \\
\mathrm{Hg}\left(\mathrm{ng} \mathrm{g}^{-1}\right)\end{array}$ & $\begin{array}{l}\text { Modern } \\
\mathrm{Hg}\left(\mathrm{ng} \mathrm{g}^{-1}\right)\end{array}$ & $\begin{array}{l}\text { Ratio between average } \\
\text { pre-industrial and modern } \\
\mathrm{Hg} \text { levels }\end{array}$ \\
\hline Crystal Lake, $\mathrm{CA}^{\mathrm{a}}$ & $110-260$ & $57-450$ & 1.1 \\
\hline Four California lakes ${ }^{b}$ & $5-39$ & $99-182$ & $2,4,5,10$ \\
\hline Lake Tahoe, $\mathrm{CA}^{\mathrm{c}}$ & $5-39$ & $157-223$ & $5^{\mathrm{d}}$ \\
\hline San Francisco, $\mathrm{CA}^{\mathrm{e}}$ & $60 \pm 10$ & $<100-1,000^{\mathrm{f}}$ & $<5$ to 20 \\
\hline
\end{tabular}

a This study, pre-industrial: pre-1865, modern: post-1965

b Sanders et al. 2008 pre-industrial: pre-1850, modern: post-1970

c Heyvaert et al. 2000, pre-industrial: pre-1850, modern: post-1980

${ }^{d}$ The authors first subtracted average pre-industrial levels from surficial $\mathrm{Hg}$ concentrations, then calculated the ratio

e Hornberger et al. 1999 baseline: pre-1850, anthropogenic influence: post-1850

${ }^{\mathrm{f}} \mathrm{Hg}$ values were estimated from Fig. 4, from Hornberger et al. 1999

et al. 2004; Mailman and Bodaly 2005), while atmospheric $\mathrm{Hg}$ levels (i.e., $\mathrm{Hg}^{\mathrm{o}}$ ) increase (Friedli et al. 2003a, b, Sigler et al. 2003). Ash may contain lower Hg levels compared to unburned soil (Biswas et al. 2007), however, Kelly et al. (2006) reported a higher release of total $\mathrm{Hg}$ and methylmercury $(\mathrm{MeHg}$ ) in burned compared to unburned catchments within one year following a fire near Moab Lake (Canada). Veiga et al. (1994) also suggested elevated Hg concentrations in the Brazilian Amazon may be due to increased erosion of $\mathrm{Hg}$-laden soil and ash resulting from slash and burn agricultural methods.

Although RDLs 1, 2, 4, and 5 corresponded to known fire history in Crystal Lake, peak Hg concentrations were not consistently observed within RDLs, and there was no statistical difference between $\mathrm{Hg}$ levels within RDLs $(n=6)$ and non-RDL sediments $(n=1)$ (ANOVA, $p>0.05)$. This implied that $\mathrm{Hg}$ was just as likely to be deposited during high erosional activity, as during "normal" periods of sedimentation. Like BBL-1, Hg was positively associated with the silt and clay fractions and inversely correlated with sand (CL-1: $r^{2}=0.51, p<0.01$, for BBL-1: $\left.r^{2}=0.52, p<0.01\right)$; however, there was no statistical difference between RDL and non-RDL layers with respect to particle size $(p>0.40)$.

Higher $\mathrm{Hg}$ concentrations in Crystal Lake sediments, and lower $\mathrm{Hg}$ enrichment compared to other sites in California (Table 4) suggested atmospheric deposition of $\mathrm{Hg}_{\mathrm{p}}$ following wild fires may be important. Wildfires and biomass burning are major sources of air pollution, including particulate matter (PM) (Sapkota et al. 2005; Zhang et al. 2008). Friedli et al. (2003a, b) reported most Hg (>88\%) emitted during a wildfire is in the form $\mathrm{Hg}^{\mathrm{o}}$, while the remaining $\mathrm{Hg}$ is bound to particulates. However, $\mathrm{Hg}_{\mathrm{p}}$ includes many $\mathrm{Hg}$ species, including $\mathrm{Hg}^{\circ}$. Feng et al. (2004) analyzed inorganic mercury species associated with airborne particulate matter, and reported the following range of $\mathrm{Hg}$ species between triplicate tests: $\mathrm{Hg}^{\mathrm{o}}(19-38 \%)$, $\mathrm{HgCl}_{2}$ (19-26\%), $\mathrm{HgO}(28-49 \%)$, and $\mathrm{HgS}(7.8-11 \%)$. Although $\mathrm{Hg}_{\mathrm{p}}$ is typically a small fraction of total $\mathrm{Hg}$ in a smoke plume, in the presence of high levels of particulates the ratio of $\mathrm{Hg}_{\mathrm{p}}: \mathrm{Hg}$ may increase. Given the estimated levels of particulates released during a fire $(6,000$ 13,000 tons of $\mathrm{PM}_{2.5}$, from Zhang et al. 2008), not all $\mathrm{Hg}^{\mathrm{o}}$ likely enters the global circulation cycle; particulates may scavenge $\mathrm{Hg}^{\circ}$, which may then be deposited directly to the earth's surface, decreasing the tropospheric residence time of emitted $\mathrm{Hg}$. In addition, there may be a time delay for erosion following fires, especially in California, where precipitation levels are low and occur 4-6 months after the fire season, while particulates from a fire may be deposited immediately after a fire. $\mathrm{Hg}$ levels spike just before the occurrence of RDLs 1,5, and 6 (Fig. 4), which may reflect atmospheric deposition of $\mathrm{Hg}_{\mathrm{p}}$ prior to erosion of sediments. Witt et al. (2009) reported total $\mathrm{Hg}$ levels in precipitation significantly increased following fires (samples collected 3-47 days postburn). Since $\mathrm{Hg}_{\mathrm{p}}$ is readily scavenged by rain, these results suggested $\mathrm{Hg}$ released from vegetation and soil during a fire was deposited through wet deposition of $\mathrm{Hg}_{\mathrm{p}}$. Findings from this study indicated dry deposition of $\mathrm{Hg}_{\mathrm{p}}$ was also important.

\section{Conclusions}

Historical wildfires regularly subsumed the forest surrounding Crystal Lake, unlike the area around Big Bear Lake, which was spared the impact of fires. Despite the close proximity of the two lakes, average $\mathrm{Hg}$ sediment concentrations at Crystal Lake were 2.2-2.8 times higher than Big Bear Lake sediments, while average $\mathrm{Hg}$ accumulation rates at Crystal Lake were 3.3 times greater. During a fire most $\mathrm{Hg}$ is released from vegetation and soil 
as $\mathrm{Hg}^{\circ}$, and may affect the global cycling of $\mathrm{Hg}$. Findings from this study suggest high levels of $\mathrm{Hg}$ remain in the vicinity following a fire, which may be deposited through dry deposition of $\mathrm{Hg}_{\mathrm{p}}$. The impacts of fires on $\mathrm{Hg}$ cycling should be further explored, since wild fires occur annually in this region, and may help explain the prevalence of $\mathrm{Hg}$ impairments in southern California water bodies. Crystal Lake and Big Bear Lake are located $~ 40-\mathrm{km}$ apart, and results indicated atmospheric deposition of $\mathrm{Hg}_{\mathrm{p}}$ following fires was confined near the fire source.

Acknowledgments This research was funded by the Big Bear Municipal Water District, the American Chemical Society/Petroleum Research Fund (\#41789-GB8) and the NSF (EAR-0318511) (to M. Kirby). This work was also funded by a NSF Career Award (BES0378483) (to J. Jay), and a NSF International Research Fellowship (\#0802014) (to S. Rothenberg). M. DeRose received an Undergraduate Research Award from California State University, Fullerton and a Grants-in-Aid-of-Research from Sigma Xi. This research was also partially supported by the State Key Laboratory of Environmental Geochemistry, Institute of Geochemistry, Chinese Academy of Sciences, in Guiyang, China. The authors thank the personnel at the Angeles National Forest Service, Eric Zhang (from the San Francisco Estuary Institute) and Sharon Landau. The authors sincerely appreciate assistance from Prof. Peter Appleby, and also acknowledge the comments from two anonymous reviewers, which greatly improved this manuscript.

Open Access This article is distributed under the terms of the Creative Commons Attribution Noncommercial License which permits any noncommercial use, distribution, and reproduction in any medium, provided the original author(s) and source are credited.

\section{References}

Amirbahman A, Ruck PL, Fernandez IJ, Haines TA, Kahl JS (2004) The effect of fire on mercury cycling in the soils of forested watersheds: Acadia national park, Maine, USA. Water Air Soil Pollut 152:313-331

Appleby P (2001) Chronostatic techniques in recent sediments. In: Last WM, Smol JP (eds) Tracking environmental change using lake sediments. Volume 1: basin analysis, coring, and chronological techniques. Kluwer Academic pp 171-203

Appleby P, Oldfield F (1978) The calculation of lead-210 dates assuming a constant rate of supply of unsupported lead-210 to the sediment. Catena 5:1-8

Bengtsson G, Picado F (2008) Mercury sorption to sediments: dependence on grain size, dissolved organic carbon, and suspended bacteria. Chemosphere 73:526-531

Big Bear Municipal Water District (BBMWD) (2008) Current lake level and precipitation history. http://www.bbmwd.org. Cited Feb 2009

Bird BW, Kirby ME (2006) An alpine lacustrine record of early Holocene North American Monsoon dynamics from Dry Lake, southern California (USA). J Paleolim 35:179-192

Biswas A, Blum JD, Klaue B, Keeler GJ (2007) Release of mercury from Rocky Mountain forest fires. Global Biogeochem Cycles. doi:10.1029/2006GB002696

Bloom NS, Crecelius EA (1983) Determination of mercury in seawater at sub-nanogram per liter levels. Mar Chem 14:49-59
Bloom NS, Fitzgerald WF (1988) Determination of volatile mercury species at the picogram level by low temperature gas chromatography with cold vapor atomic fluorescence detection. Anal Chim Acta 208:151-161

Brown S, Bierman P, Lini A, Davis PT, Southon J (2002) Reconstructing lake and drainage basin history using terrestrial sediment layers: analysis of cores from a post-glacial lake in New England, USA. J Paleolim 28:219-236

Brunke E-G, Labuschagne C, Slemr F (2001) Gaseous mercury emissions from a fire in the Cape Peninsula, South Africa, during January. Geophys Res Lett 28:1483-1486

Caldwell CA, Canavaan CM, Bloom NS (2000) Potential effects of a forest fire and storm flow on total mercury and methylmercury in sediments of an arid-lands reservoir. Sci Total Environ 260:125-133

Callender E, Rice KC (2000) The urban environmental gradient: anthropogenic influences on the spatial and temporal distributions of lead and zinc in sediments. Environ Sci Technol 34:232-238

Chen CY, Folt CL (2005) High plankton densities reduce mercury biomagnification. Environ Sci Technol 39:115-121

Conrad M (2003) A brief history of Crystal Lake, Angeles National Forest. $7 \mathrm{pp}$

Crusius J, Anderson RF (1995) Evaluating the mobility of ${ }^{137} \mathrm{Cs}$, ${ }^{239+240} \mathrm{Pu}$ and ${ }^{210} \mathrm{~Pb}$ from their distributions in laminated lake sediments. J Paleolimnol 13:119-141

Dean WE (1974) Determination of carbonate and organic matter in calcareous sedimentary rocks by loss on ignition: comparison with other methods. J Sediment Petrol 44:242-248

DiCosty RJ, Callaham MA Jr, Stanturf JA (2006) Atmospheric deposition and re-emission of mercury estimated in a prescribed forest-fire experiment in Florida, USA. Water Air Soil Pollut 176:77-91

Engle MA, Gustin MS, Johnson DW, Murphy JF, Miller WW, Walker RF, Wright J, Markee M (2006) Mercury distribution in two Sierran forest and one desert sagebrush steppe ecosystems and the effects of fire. Sci Total Environ 367:222-233

Feng XB, Lu JY, Grègoire DC, Hao YJ, Banic CM, Schroeder WH (2004) Analysis of inorganic mercury species associated with airborne particulate matter/aerosols: method development. Anal Bioanal Chem 380:683-689

Flynn WW (1968) The determination of low levels of Po-210 in environmental materials. Anal Chim Acta 43:221-227

Friedli HR, Radke LF, Lu JY (2001) Mercury in smoke from biomass fires. Geophys Res Lett 28:3223-3226

Friedli HR, Radke LF, Lu JY, Banic CM, Leaitch WR, MacPherson JI (2003a) Mercury emissions from burning of biomass from temperate North American forests: laboratory and airborne measurements. Atmos Environ 37:253-267

Friedli HR, Radke LF, Prescott R, Hobb PV, Sinha P (2003b) Mercury emissions from the August 2001 wildfires in Washington State and an agricultural waste fire in Oregon and atmospheric mercury budget estimates. Global Biogeochem Cycles. doi:10.1029/2002GB001972

Fukue M, Yanai M, Sato Y, Fujikawa T, Furukawa Y, Tani S (2006) Background values for evaluation of heavy metal contamination in sediments. J Hazard Mater 136:111-119

Goforth BR, Minnich RA (2007) Evidence, exaggeration, and error in historical accounts of chaparral wildfires in California. Ecol Appl 17:779-790

Gresswell RE (1999) Fish and aquatic ecosystems in forested biomes of North America. Trans Am Fish Soc 128:193-221

Harden JW, Neff JC, Sandberg DV, Turetsky MR, Ottmar R, Gleixner G, Fries TL, Manies KL (2004) Chemistry of burning the forest floor during the FROSTFIRE experimental burn, interior Alaska, 1999. Global Biogeochem Cycles. doi:10.1029/2003GB002194

Heyvaert AC, Reuter JE, Slotton DG, Goldman CR (2000) Paleolimnological reconstruction of historical atmospheric lead and 
mercury deposition at Lake Tahoe, California-Nevada. Environ Sci Technol 34:3588-3597

Hornberger MI, Luoma SN, van Geen A, Fuller C, Anima R (1999) Historical trends of metals in the sediments of San Francisco Bay, California. Mar Chem 64:39-55

Kelly EN, Schindler DW, St. Louis VL, Donald DB, Vladicka KE (2006) Forest fire increases mercury accumulation by fishes via food web restructuring and increased mercury inputs. PNAS 103:19380-19385

Krishnaswami S, Lal D, Martin JM, Maybeck M (1971) Geochronology of lake sediments. Earth Planet Sci Lett 11:407-414

Lindberg S, Bullock R, Ebinghaus R, Engstrom D, Feng X, Fitzgerald W, Pirrone N, Prestbo E, Seigneur C (2007) Synthesis of progress and uncertainties in attributing the sources of mercury in deposition. Ambio 36:19-32

Lockhart WL, Macdonald RW, Outridge PM, Wilkinson P, DeLaronde JB, Rudd JWM (2000) Tests of fidelity of lake sediment core records of mercury deposition to known histories of mercury contamination. Sci Total Environ 260:171-180

Los Angeles Regional Water Quality Control Board (LARWQCB) (1994) Water quality control plan, Los Angeles region: chapter 2 beneficial uses. http://www.waterboards.ca.gov/losangeles/water_ issues/programs/basin_plan/basin_plan_documentation.shtml. Cited Feb 2009

Mailman M, Bodaly RA (2005) Total mercury, methyl mercury, and carbon in fresh and burned plants and soil in Northwestern Ontario. Environ Pollut 138:161-166

Malmon DV, Reneau SL, Katzman D, Lavine A, Lyman J (2007). Suspended sediment transport in an ephemeral stream following wildfire. J Geophys Res. doi:10.1029/2005JF000459

Mathieu GG (1977) Rn-222-Ra-226 technique of analysis. Annual technical report C00-2185-0. Lamont-Doherty Geological Observatory, Palisades, NY

Minnich RA (1987) Fire behavior in southern California chaparral before fire control- the Mount Wilson burns at the turn of the century. Ann Assoc Am Geogr 77:599-618

Minshall GW, Brock JT, Varley JD (1989) Wildfires and Yellowstone's stream ecosystems. Bioscience 39:707-715

Noda A, TuZino T, Kanai Y, Furukawa R, Uchida J-I (2008) Paleoseismicity along the southern Kuril Trench deduced from submarine-fan turbidites. Mar Geol 254:73-90

Onda Y, Dietrich WE, Booker F (2008) Evolution of overland flow after a severe forest fire, Point Reyes, California. Cantena 72:13-20

Pickhardt PC, Folt CL, Chen CY, Klaue B, Blum JD (2005) Impacts of zooplankton composition and algal enrichment on the accumulation of mercury in an experimental freshwater food web. Sci Total Environ 339:89-101

Plumlee GS, Martin DA, Hoefen T, Kokaly R, Hageman P, Eckberg A, Meeker GP, Adams M, Anthony M, Lamothe PJ (2007) Preliminary analytical results for ash and burned soils from the October 2007 southern California wildfires. USGS Open-File Report 2007-1407

Rasmussen PE (1994) Current methods of estimating atmospheric mercury fluxes in remote areas. Environ Sci Technol 28:22332241

Ritchie JC, McHenry JR (1990) Application of radioactive fallout cesium-137 for measuring soil erosion and sediment accumulation rates and patterns: a review. J Environ Qual 19:215-233

Robbins JA, Edgington DH (1975) Determination of recent sedimentation rates in Lake Michigan using $\mathrm{Pb}-210$ and $\mathrm{Cs}-137$. Geo Cosmo Acta 39:285-304

Rodbell DT, Abbott MB, Enfield DB, Newman JH (1999) An 15, 000-year record of El Nino-driven alluviation in Southwestern Ecuador. Science 283:516-520

Rydberg J, Gälman V, Renberg I, Bindler R, Lambertsson L, Martínez-Cortizas A (2008) Assessing the stability of mercury and methylmercury in a varved lake sediment deposit. Environ Sci Technol 42:4391-4396

Sanders RD, Coale KH, Gill GA, Andrews AH, Stephenson M (2008) Recent increase in atmospheric deposition of mercury to California aquatic systems inferred from a 300-year geochronological assessment of lake sediments. Appl Geochem 23:399-407

Sapkota A, Symons JM, Kleissl J, Wang L, Parlange MB, Ondov J, Breysse PN, Diette GB, Eggleston PA, Buckley TJ (2005) Impact of the 2002 Canadian forest fires on particulate matter air quality in Baltimore City. Environ Sci Tech 39:24-32

Schroeder W, Munthe J (1998) Atmospheric mercury-an overview. Atmos Envt 32:809-822

Schuster E (1991) The behavior of mercury in the soil with special emphasis on complexation and adsorption processes-a review of the literature. Water Air Soil Pollut 56:667-680

Shakesby RA, Doerr SH (2006) Wildfire as a hydrological and geomorphological agent. Earth Sci Rev 74:269-307

Siegfried CA, Herrgesell PL, Kopache ME (1982) Limnology of a eutrophic reservoir: Big Bear Lake, California. Calif Fish Game 68:90-108

Sigler JM, Lee X, Munger W (2003) Emission and long-range transport of gaseous mercury from a large scale Canadian boreal forest fire. Environ Sci Technol 37:4343-4347

Spencer CN, Gabel KO, Hauer FR (2003) Wildfire effects on stream food webs and nutrient dynamics in Glacier National Park, USA. For Ecol Manage 178:141-153

St-Onge G, Mulder T, Piper DJW, Hillaire-Marcel C, Stoner JS (2004) Earthquake and flood-induced turbidites in the Saguenay Fjord (Québec): a Holocene paleoseismicity record. Quat Sci Rev 23:283-294

U.S. Department of Agriculture Forest Service (USDAFS) (2008) California Fire History: CA_R5_FireHistory07_1. http://www.fs. fed.us/r5/rsl/clearinghouse/gis-download.shtml. Cited Feb 2009

U.S. Department of Agriculture Natural Resources Conservation Service (USDANRCS) (1999) California Interagency Watershed Map, CalWater Version 2.2.1. http://www.ca.nrcs.usda.gov/ features/calwater. Cited Feb 2009

U.S. E.P.A. (USEPA) (1998) Method 7473, mercury in solids and solutions by thermal decomposition, amalgamation and atomic absorption spectrophotometry. Washington, DC

U.S. E.P.A. (USEPA) (2001) Water quality criterion for the protection of human health: Methylmercury, EPA-823-R-01001. U.S. EPA, Office of Water, Washington, DC. http://www. epa.gov/waterscience/criteria/methylmercury/document.html. Cited Feb 2009

U.S. E.P.A. (USEPA) (2002) Method 1631, Revision E: mercury in water by oxidation, purge and trap, and cold vapor atomic fluorescence spectrometry. Washington, DC

U.S. E.P.A. (USEPA) (2008) Impaired waters and total maximum daily loads. http://www.epa.gov/owow/tmdl. Cited Feb 2009

Veiga MM, Meech JA, Onate N (1994) Mercury pollution from deforestation. Nature 368:816-817

Wiedinmyer C, Friedli H (2007) Mercury emission estimates from fires: an initial inventory for the United States. Environ Sci Technol 41:8092-8098

Wilkinson P (1985) The determination of environmental levels of uranium and thorium series isotopes and Cs-137 in aquatic and terrestrial samples, vol 78. Canadian Special Publication of Fisheries and Aquatic Sciences, Canada, $51 \mathrm{p}$

Witt EL, Kolka RK, Nater EA, Wickman TR (2009) Forest fire effects on mercury deposition in the boreal forest. Environ Sci Technol 43:1776-1782

Zhang XY, Kondragunta S, Schmidt C, Kogan F (2008) Near real time monitoring of biomass burning particulate emissions (PM2.5) across contiguous United States using multiple satellite instruments. Atmos Environ 42:6959-6972 